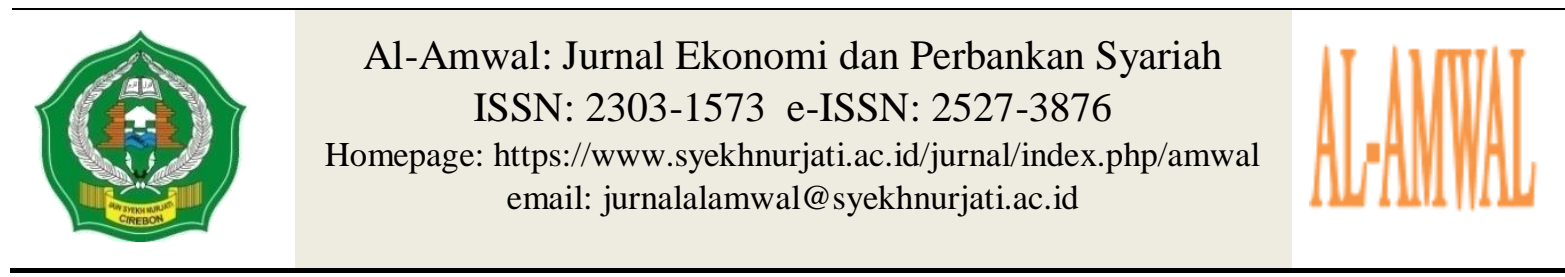

\title{
Can the Efficiency of Islamic Banks in Indonesia Improve Their Competitiveness?
}

\author{
Muhammad Iqbal \\ Perbanas Institute \\ Email:iqbal@perbanas.id \\ Dwi Yanti Yunianita \\ Perbanas Institute \\ Email: d.yuniianita@gmail.com
}

\begin{abstract}
The development of Islamic banks today has contributed to the emergence of increasingly competitive competition between Islamic banks. Efficiency performance is believed to be a major factor in driving competitiveness among Islamic banks. This study aims to analyze the efficiency performance of Islamic banks in Indonesia and their effect on competitiveness. The sample used was 11 Islamic banks in Indonesia. The data used in this study were obtained from annual financial reports published from the OJK website and each bank during the period of 2012 - 2017. The approach used to measure efficiency performance uses the Data Envelopment Analysis (DEA) method, while the data analysis method uses OneWay ANOVA and panel data regression. The results of measuring the efficiency performance of Islamic banks in Indonesia are still quite efficient, although during the study period several banks experienced a decrease in efficiency which resulted in differences in efficiency of performance among Islamic banks. Changes in efficiency performance do not have an impact on the competitiveness of Islamic banks themselves.
\end{abstract}

Keywords: efficiency, data envelopment analysis, competitiveness

\begin{abstract}
Abstrak
Perkembangan bank syariah dewasa ini turut mendorong munculnya persaingan antar bank syariah yang semakin kompetitif. Kinerja efisiensi dipercaya menjadi factor utama dalam mendorong daya saing antar bank syariah. Penelitian ini bertujuan menganalisis kinerja efisiensi bank syariah di Indonesia serta pengaruhnya terhadap daya saing. Sampel yang digunakan sebanyak 11 bank umum syariah di Indonesia. Data yang digunakan dalam studi ini diperoleh dari laporan keuangan tahunan yang telah dipublikasi dari situs OJK dan masing-masing bank selama periode tahun 2012 - 2017. Pendekatan yang dipakai untuk
\end{abstract}


mengukur kinerja efisiensi menggunakan metode Data Envelopment Analysis (DEA), sedangkan metode analisis datanya menggunakan One Way ANOVA dan regresi data panel. Hasil pengukuran kinerja efisiensi bank syariah di Indonesia masih tergolong cukup efisien meskipun selama periode penelitian beberapa bank mengalami penurunan efisiensi yang berdampak kepada perbedaan kinerja efisiensi antar bank syariah. Perubahan kinerja efisiensi tidak memberikan dampak terhadap daya saing bank syariah itu sendiri.

Kata kunci: efisiensi, Data Envelopment Analysis, daya saing

\section{INTRODUCTION}

Since the emergence and development of Islamic banks in Muslim countries, there is an assessment that Islamic banks should get more place in the hearts of the Muslim population, especially in Indonesia. Customers who have a high level of religiosity will still choose Islamic banks even though the return obtained will be lower. They can choose to place their funds in any Islamic bank they want because there are many choices of Islamic banks in the banking industry today(Risfandy, Husa \& Asrihapsari, 2016).

The Financial Services Authority (OJK) reports that in November 2016 there were 13 Sharia Commercial Banks (BUS), 21 Sharia Business Units (UUS), and 164 Sharia Rural Banks (BPRS). As of February 2017 the number of BUSs had not increased, neither did UUS and BPRS (Rosyadi, 2017).But in November 2019 the number of BUS has increased to 14 while UUS has decreased to 20. In order to highlight the development of Islamic banks which are currently attracting the attention of many people, as has been revealed by Risfandy et al., (2016)that Bank Indonesia (BI) must consider alternative methods in boosting the competitiveness of Islamic banks because the balance of the two types of banks can improve financial stability.

To be able to find out how much the level of competitiveness of Islamic banks must first understand the performance in a company. In this case the growth of sharia banks seems to experience a significant acceleration, this is because the sharia unit can offer separate sharia banking products (Huda \& Nasution, 2014). While Ramly \& Hakim (2017) states that one important aspect in the development of Islamic banks is competition between Islamic banks and conventional banks. Not only that, fellow Islamic banks also experience intense competition. The level of competition is considered as one of the positive factors in influencing bank efficiency, productivity and innovation. This is in line with the findings of Casu \& Girardone (2009) and Schaeck \& Čihák (2008), which state that competition between banks is able to influence bank performance, one of which has a positive impact on efficiency (Hafidz \& Astuti, 2013).

Various studies on banking efficiency have been carried out by previous researchers, including many who use the DEA (Data Envelopment Analysis) method (Amirillah, 2014; Cahyaningsih, Purnomo, Harun, \& Hasmarini, 2017; Edward, 2013; Hafidz \& Astuti, 2013; Hidayati, Siregar \& Pasaribu, 2017; Loong, Kamarudin, Sufian, \& Naseem, 2017; Ramly \& Hakim, 2017). The results of previous studies turned out to have mixed results, as shown by Hidayati et al., (2017) as a whole the development of the level of efficiency of BUS and UUS has fluctuating trends. This shows that BUS and UUS in Indonesia are categorized inefficient or not optimal in managing their resources. This is also in line with research conducted by Cahyaningsih et al., (2017) which says that each Islamic bank is not always the same in increasing its efficiency. The results contradict the findings of Amirillah (2014) and Edward (2013) which stated that the average efficiency score in Islamic banks reached $99.49 \%$. Hidayati et al., (2017) and Cahyaningsih et al., (2017) is not in line with the results of research conducted by Loong et al., (2017) which states that domestic Islamic banks exhibit 
higher technical efficiency than Islamic banks in Indonesia, Malaysia and Brunei at a significance level of $1 \%$.

Meanwhile, research on the competitiveness of Islamic banks is still little done. One method of measuring bank competitiveness is the RCA (Revealed Comparative Advantages) method. In the research ofBalassa (1965) dan Edward (2013)stated that the RCA aims to analyze the comparative advantage of a commodity in a country. Initially the RCA method was intended to measure the export performance of a commodity from a country by evaluating the role of certain commodity exports in world trade. But after that Adam (1996) himself cited a previous researcher, Bela Balassa (1965), and the study successfully described the competitiveness of the national Textile and Textile Products (TPT) industry against the ASEAN TPT industry. It's just that Adam (1996) tried to focus on the competitiveness of the TPT industry and relate it to the relative competitiveness of each ASEAN country. This study measures the success of banks in increasing efficiency while controlling competitiveness, so as to become an efficient bank and have superior competitiveness.

Edward (2013)revealed that the national banking industry succeeded in making efficiency, but failed to improve competitiveness. Conversely, there are banks that have succeeded in increasing competitiveness, but in the process are inefficient or wasteful. However, there are several banks that are able to increase efficiency while being able to increase competitiveness (Edward, 2013). This is different from the fact that there is growth in the market share of Islamic banks themselves are generally still relatively small at $5 \%$. Competition between banks may occur due to the struggle over productive resources, for example on deposits, savings, and the distribution of financing which is a source of income. So that this can lead to competition and effectiveness of Islamic banks.

\section{LITERATURE REVIEW}

\section{Islamic Bank}

Islamic banks are banks whose business activities are based on sharia principles, namely prohibiting the existence of a system of interest or usury. While Islamic banking is everything that concerns about Islamic banks and Islamic business units, including institutions, business activities, as well as ways and processes in carrying out their business activities (Riyadi, 2017).

Ismail (2011)states that Islamic commercial banks are banks that are independent in accordance with their deed of establishment, not part of conventional banks. This is adjusted to Law No. 21 of 2008 concerning Sharia Banking, Sharia Banks are banks that carry out business activities based on sharia principles, or Islamic legal principles regulated in the fatwa of the Indonesian Ulema Council (MUI) such as the principles of justice and balance ('adl wa tawazun), benefit (maslahah), universalism (natural), and does not contain gharar, maysir, usury, wrongdoing and haram objects.

\section{Efficiency}

In an organization, performance is the ability possessed in implementing strategies effectively to ensure all the objectives to be achieved can be realized. Initially an evaluation of a bank's performance is measured by financial ratios, such as the capital adequacy ratio (CAR), Loan To Deposit Ratio (LDR), Net Profit Margin (NPM), Return on Assets (ROA) and others known as CAMEL. Performance measurement based on these ratios cannot directly measure the level of efficiency achieved by a bank compared to other banks. Instead this ratio is often associated with soundness or prediction of failure in the banking business (Nadiasari, 2018).

The CAMEL analysis relating to the soundness of the bank's aim is to find out the actual condition of the bank whether in a healthy, unhealthy or possibly unhealthy condition 
(Khasanah \& Laksito, 2010). From the assessment of the soundness of this bank will ultimately show how the bank's performance.

When efficiency is introduced in order to see the extent to which a company's performance can run optimally through different methods, Charnes, Cooper \& Rhodes (CCR) were the first to introduce the DEA approach in 1978 in measuring the level of efficiency. Wahab (2015)also revealed that banking performance can be measured using efficiency. The level of efficiency of a bank can reflect the extent to which companies manage resources for optimal use.

In realizing the target of the development of Islamic banking, the analysis of banking performance efficiency is one of the benchmarks. This is done in order to find out whether a bank has optimally contributed to the community (Karsinah \& Cahya, 2014). Meanwhile,Wijayanto \& Sutarno (2010)also explained that efficiency is a way to achieve the desired results by comparing input and output. Efficiency for a bank as a whole is an important aspect that is considered to create a healthy and sustainable financial performance. The bank can find out which inputs are not used efficiently, and which outputs must be increased by available inputs. The level of efficiency achieved is a reflection of good quality performance(Nadiasari, 2018).

This is in line with previous research conducted by(Fathony, 2017; Hidayati et al., 2017)which states that efficiency can be interpreted by adjusting the results between input and output. Efficiency is a picture of a company's performance and is an important aspect to achieve a healthy and sustainable financial performance. Efficiency becomes one of the indicators to analyze the performance of a bank as well as the performance parameters of an organization, including banks. Berger and Mester (1997), viewed banking efficiency from two sides, namely in terms of cost (cost efficiency) and in terms of profit (profit efficiency). In terms of costs, a bank is assessed by comparing banks that have the best practice bank's costs that produce the same output and technology.

While in terms of profit measures the level of efficiency of a bank's ability to generate profits or profits on each unit of input used (Basyarah, 2016). According to Hadad, Hall, Kenjegalieva, Santoso, \& Simper (2011), there are three approaches used in defining the relationship between input and output in the financial activities of a financial institution, namely: the production approach, the intermediation approach and the asset approach.

The most appropriate intermediation approach is used in the banking world, this is in line with previous studies (Akbar, 2014; Cahyaningsih et al., 2017; Hidayati et al., 2017). See Islamic banks as one of the financial institutions that function as intermediaries in financial services, which change and transfer financial assets from surplus units to deficit units in order to meet the needs and desires of the community.

Islamic banks have now expanded their network of units to 184 Islamic banks consisting of 14 BUS, 20 UUS and 164 BPRS. This indicates that competition among Islamic banks is increasingly high so that Islamic banks must always improve products and services that are superior and quality. However, as its expansion has grown, several problems have arisen, including the improvement of the quality of existing banks, both in terms of performance and health (Muharam, 2007). Then comparing the conditions between one Islamic bank and another Islamic bank also feels necessary to see whether each Islamic bank has the same or different efficiency performance? This is done to encourage banks to carry out strategies in anticipating the decline in the level of performance in a company or banking institution appropriately. With the rapid development of Islamic banks today it is expected to be able to optimize its performance as a study conducted by Hidayati et al. (2017) that Islamic commercial banks in Indonesia are technically not yet fully operating efficiently, so it is necessary to measure the level of efficiency between Islamic banks in Indonesia. For this reason, the first hypothesis is proposed: 
$\mathrm{H}_{1}$ : there is a difference in the efficiency performance between Islamic banks from one another.

\section{Efficiency Measurement}

Charnes, Cooper \& Rhodes (CCR) were the first to introduce the DEA approach in 1978 to evaluate the relative efficiency of Decision Making Units (DMU) in an organization by giving weight to inputs or outputs (Wijayanto \& Sutarno, 2010).

The efficiency of a company consists of two components, namely: 1) technical efficiency and 2) allocative efficiency. Technical efficiency describes the company's ability to achieve maximum output levels using certain input levels. This technique measures the production process that produces maximum output by using a minimum number of inputs, in other words this technique reflects the company's ability to produce maximum output using a number of available inputs. Meanwhile, allocative efficiency describes a company's ability to optimize the use of its inputs with certain price structures and technologies. The combination of technical efficiency and allocative efficiency will become economic efficiency.

According toTanjung \& Devi (2013), the stages in using DEA, namely:

1. Determine the DMU

DMU is an operational unit that will be used as a decision-making entity or business unit to be tested for efficiency. DMU can be a profit oriented or nonprofit oriented company.

2. Determine the Approach

Achievement of operational objectives in each unit can be used as an approach to measure "good performance". In the banking industry itself there are 3 different types of approaches to measure the level of performance of banking activities. According to Tanjung \& Devi (2013) the efficiency approach is divided into three, namely:

a. Production approach

b. Intermediation approach

c. Asset approach

In the selection of this approach will affect the determination of input-output variables that will be used for efficiency testing.

3. Selecting Input-Output Variables

The selection of input-output variables is usually based on the type of approach chosen by each researcher.

4. Collecting Data

After all data is defined (DMU, approaches, and input-output variables) the next step is to find and collect data. In collecting data no blank values (0) are allowed on each data from the collected DMU. The number of DMUs must be more than the total number of input-output variables.

5. Select the DEA Model

Determination of the DEA model will affect subsequent analysis, whether it will be oriented to the input or output. In choosing the DEA model, there are 3 types of models used in the study, namely:

a. CCR (CRS) constant return to scale which results in overall technical efficiency.

b. BCC (VRS) variable return to scale which results in pure technical efficiency.

c. CCR / BCC (OTE) overall technical efficiency which results in scale efficiency.

6. Synthesis and Analysis

Efficiency measurement can be done using a non-parametric method namely Data Envelopment Analysis (DEA). In the DEA concept there are two approaches, namely input and output. Inputs are used to answer how much the quantity of inputs can be reduced proportionally to produce the same quantity of output. While output is used to answer how 
much the quantity of inputs can be reduced proportionally to produce the same quantity of output(Tanjung \& Devi, 2013).

\section{Competitiveness}

According to Edward (2013)the most popular concept of competitiveness and is often used as a theoretical basis is the Porter Five Forces Analysis, which is the five forces of Porter's analysis (1998). Porter's theory is a framework for industrial analysis and business strategy development developed by Michael E. Porter of Harvard Business School in 1997. Porter in his analysis uses the principles of development, industrial organization of the economy to reduce the five forces that determine competitive intensity, it is the appeal of the market.

Porter stated that the five competing forces could develop competitive strategies by influencing or changing these strengths so as to provide a favorable situation for the company. The scope of the five competitive forces, among others, first, the threat of new entrants, which can be determined by barriers to entry into the industry, among others, price barriers, incumbent response, high costs, incumbent experience in the industry, cost advantage, product differentiation, distribution access, government policy and switching costs. Second, supplier bargaining power, which is influenced by several factors including the level of market concentration, diversification, switching costs, supplier organizations and the government. Third, the bargaining power of buyers, which is influenced by various factors, including differentiation, concentration, buyer's interests, income level, choice of product quality, access to information, and switching costs. Fourth, the threat of substitute products, which is determined by the price of substitute products, switching costs, and product quality. Fifth, competition in the industry, which is determined by various factors, namely market growth, cost structure, industry exit barriers, switching costs, experience in the industry, and differences in the strategies adopted.

Edward (2013)To measure the competitiveness of banks can be measured from the total assets owned, then combined with the application of deposit interest rates and the application of credit interest at each bank. The output of each bank's policy will generate net interest income (NIM), of course, will eventually record net income. Because it is interesting to examine how the polarization of competition in determining the deposit and loan interest rates. Because banks apply various types of deposits and types of credit, what can be used as a reference is the deposit rate and the base rate of credit (SBDK).

Calculation of the level of competition is important. Interbank competition can occur because of struggles over productive resources, for example on deposits, savings and lending which are sources of income. Non-interbank price competition can be in the form of prizes or promotions aimed at reaching as many customers as possible. In addition, competition can also take the form of new products and services supported by technological developments that can reduce production and distribution costs.

Meanwhile, to measure competitiveness using the Revealed Comparative Advantage (RCA) model. The value of this index is between 0 to 1 . The higher the index value reflects the increasingly concentrated market and the lower level of competition (Risfandy et al., 2016).Initially the RCA aimed to analyze the comparative advantage of a commodity in a country. RCA is one method used to measure the export performance of a commodity from a country by evaluating the role of certain commodity exports in the total exports of a country compared to the share of these commodities in world trade. This RCA concept was first introduced by Ballasa in 1965, which considers that the comparative advantage of a country is reflected or revealed in its exports (Karlinda, 2012).

The more efficient a bank is expected to be, the more competitive it will be with other banks. Hafidz \& Astuti (2013) menuturkan bahwa analisis hubungan antara kompetisi dan 
efisiensi perbankan dapat dilakukan dengan mengkuti teori Competition-Efficiency Hypothesis. Kemudian hasil dari penelitiannya menyatakan bahwa semakin meningkatnya tingkat persaingan bank, maka akan mendorong bank untuk berusaha lebih efisien. Sehingga dapat diajukan hipotesis kedua, yaitu:

$\mathrm{H}_{2}$ : efficiency performance affects the competitiveness of Islamic banks in Indonesia.

\section{METHODE}

The type of data used in this study is historical quantitative data, obtained from BUS financial reports and Islamic Banking Statistics in Indonesia. The data collection method used is documentation originating from written sources in the form of financial reports from each bank obtained from the OJK website for the 2012-2017 period. The population in this study was 13 BUS in Indonesia. Sampling in this study was conducted by purposive sampling method. A good sample is expected to represent the population or representative (Sugiarto, 2016). The samples used in this study were only 11 Islamic banks with details as listed in table 1.

Table1. List of Sharia Commercial Banks in Indonesia

\begin{tabular}{cll}
\hline No & Bank Code & \multicolumn{1}{c}{ Bank Name } \\
\hline 1 & BMI & PT. Bank Muamalat Indonesia \\
2 & BMSI & PT. Bank Mega Syariah Indonesia \\
3 & BCAS & PT. Bank BCA Syariah \\
4 & BNIS & PT. Bank BNI Syariah \\
5 & BRIS & PT. Bank BRI Syariah \\
6 & BSM & PT. Bank Syariah Mandiri \\
7 & BJBS & PT. Bank Jabar Banten Syariah \\
8 & BPS & PT. Bank Panin Syariah \\
9 & BBS & PT. Bank Bukopin Syariah \\
10 & BVS & PT. Bank Victoria Syariah \\
11 & MBS & PT. Maybank Syariah \\
\hline
\end{tabular}

Source: OJK (2017)

The variable used in this study is the efficiency of Islamic banks which will be measured using the Data Envelopment Analysis (DEA) method in predicting the level of efficiency between Islamic banks. In this method the intermediation approach is used with input variables: savings, assets and labor and outputs: financing, income and total income. While the DEA model used is a variable return to scale (VRS). The DEA indicators are measured from the results of evaluations in the financial statements in the form of deposits, assets, labor, financing, operating income and total income obtained from the publication of reports in the financial statements of each Sharia Commercial Bank. The yield criteria for the DEA method will show a scale of 0 to 1 , where if the efficiency results show the number 0 then the unit being tested is very inefficient. Whereas if the efficiency results show the number 1, the units tested are very efficient (Tanjung \& Devi, 2013).

Then to see the competitiveness score among Islamic banks, then it is done by using the Revealed Comparative Advantages (RCA) method or the Competitive Advantage Index. RCA is an advantage possessed by a country or nation to be able to compete in the international market. This method aims to analyze the comparative advantage of a commodity in a country. This RCA concept was first introduced by Balassa in 1965, which 
considers that the comparative advantage of a country is reflected or revealed in its exports (Karlinda, 2012). The model can be modified by Edward (2013)as follows:

$R C A_{i}=\left[\frac{N L_{i}+O E A_{i}}{T A_{i}}\right]:\left[\frac{\sum N L_{i}+\sum O E A_{i}}{\sum T A_{i}}\right]$

Where:

$\mathrm{RCA}_{\mathrm{i}}=$ Revealed Comparative Advantage bank- $\mathrm{i}$

$\mathrm{NL}_{\mathrm{i}} \quad=$ Net Loan

OEA $_{\mathrm{i}}=$ Others Earning Assets, placement of interbank bank-i funds to other banks plus bank-i investment in portfolios (securities, government bonds, derivatives)

$\mathrm{TA}_{\mathrm{i}} \quad=$ Total Asset bank-i

$\sum \mathrm{NL}_{\mathrm{i}} \quad=$ Net Loan banking industry

$\sum \mathrm{OEA}_{\mathrm{i}}=$ Others Earning Assets banking industry

$\sum \mathrm{TA}_{\mathrm{i}}=$ Total Asset banking industry

The RCA indicator is more projected on the ratio of net loans, others earning assets, total assets, $\sum$ net loan, $\sum$ others earning assets, and $\sum$ total assets. The criteria for the results of this RCA method is to be able to know how the condition of a company's competitiveness, whether its competitiveness is low or high. If the higher the value of RCA, means the higher the competitiveness, and vice versa(Edward, 2013). Limitation on the value of competitiveness, namely:

RCA $>1=$ high competitiveness

$\mathrm{RCA} \leq 1=$ low competitiveness

After knowing the measurement results of the two methods used, the One Way Anova test and the Panel Data Regression were then performed. According to Sugiarto (2016)One Way Anova is a technique in statistics that is useful for examining differences between means (average) in two or more populations. The One Way Anova test is used to see whether each Islamic bank that is a research sample has a different or the same level of efficiency. Finally, a panel data regression is aimed at looking at the inseparable economic impacts between individuals over several periods, and this cannot be obtained from the use of cross section data or time series data separately (Iqbal, 2015). Tests on panel data are also used to find out whether each Islamic bank studied has an influence or not in increasing its efficiency and competitiveness.

\section{RESULTS AND DISCUSSION}

The stages in measuring efficiency with the DEA analysis method, begins with determining the decision making unit (DMU). DMU can be a profit-oriented or non-profit oriented company, in this case Bank Syariah was chosen to be a DMU. Then determine the approach, in this case the approach used is an intermediation approach with input variables: savings, assets and labor and its output financing, income and total income. After selecting the approach and input-output used, the next step is to collect data from the 11 DMUs or Islamic Banks that have been selected and then the data is adjusted to the use of inputs and outputs. After determining the input-output and collecting data, the next step is to choose the DEA model with the chosen model is VRS (Variable Return to Scale). The final stage is doing synthesis and analysis, or the results / outputs of the DEA method. The result score from DEA calculation will show a scale from 0 to 1 , where if the result of DEA method 
calculation shows 0 then the unit tested is inefficient. Whereas if the efficiency results show the number 1, the unit tested is efficient. The results of data processing conducted by the DEA method with the VRS model approach show that the average Islamic bank has reached the level of perfect efficiency, although there are some banks that have not reached the level of efficiency, this can be seen from the score of the calculation of the efficiency of each Islamic bank as listed in Table 2.

Table 2. The Calculation Results Data Envelopment Analysis (DEA)

\begin{tabular}{|c|c|c|c|c|c|c|c|}
\hline \multirow{2}{*}{ Bank Code } & \multicolumn{6}{|c|}{ Year } & \multirow{2}{*}{ Finding } \\
\hline & 2012 & 2013 & 2014 & 2015 & 2016 & 2017 & \\
\hline BMI & 1,000 & 1,000 & 1,000 & 1,000 & 1,000 & 1,000 & Efficient \\
\hline BMSI & 1,000 & 1,000 & 1,000 & 1,000 & 0,966 & 0,891 & Inefficient \\
\hline BCAS & 1,000 & 1,000 & 1,000 & 0,964 & 0,966 & 1,000 & Inefficient \\
\hline BNIS & 1,000 & 1,000 & 1,000 & 1,000 & 1,000 & 0,983 & Inefficient \\
\hline BRIS & 1,000 & 1,000 & 1,000 & 1,000 & 1,000 & 1,000 & Efficient \\
\hline BSM & 1,000 & 1,000 & 1,000 & 1,000 & 1,000 & 1,000 & Efficient \\
\hline BJBS & 1,000 & 1,000 & 1,000 & 1,000 & 0,906 & 1,000 & Inefficient \\
\hline BPS & 1,000 & 1,000 & 1,000 & 1,000 & 1,000 & 1,000 & Efficient \\
\hline BBS & 0,973 & 0,893 & 0,947 & 0,958 & 0,992 & 0,918 & Inefficient \\
\hline BVS & 1,000 & 1,000 & 1,000 & 1,000 & 1,000 & 1,000 & Efficient \\
\hline MBS & 1,000 & 1,000 & 1,000 & 1,000 & 1,000 & 1,000 & Efficient \\
\hline
\end{tabular}

Souce: Output results DEAP 2.1 (2019)

Based on the results of data processing in Table 2. it can be seen that the number of banks that reached $100 \%$ perfect efficiency level were 6 banks from the whole group. Based on the efficiency scores of each Islamic commercial bank, the data above shows that there are banks that have perfect efficiency scores from 2012 to 2017, namely Bank Muamalat (BMI), Bank Rakyat Indonesia Syariah (BRIS), Bank Syariah Mandiri (BSM), Bank Panin Syariah (BPS), Bank Victoria Syariah (BVS) and Maybank Syariah (MBS). Banks with perfect efficiency levels will be seen on the resulting scale, which is 1 or $100 \%$. The figures generated on this efficiency scale can identify units of economic activity that are not going well or not productive. So that banks can easily find other alternatives to avoid the risk of losses obtained.

While the sharia bank which is almost close to efficiency is the BCAS but there has been a decline so that the efficiency score in 2015 was 0.964 and in 2016 it was 0.966 and the Jabar Banten Syariah Bank had experienced inefficiency in 2016 which amounted to 0.906. At Bank Bukopin Syariah there is no visible increase in efficiency scores where the calculation results at Bank Bukopin Syariah are only 0.918 or less than 1, which means that it has not reached a perfect level of efficiency. While sharia banks that experienced inefficiency in 2017, namely BNI Syariah amounted to 0.983 .

The use of the One Way Anova method to test the first hypothesis shows that there are differences in the level of efficiency between Islamic banks in Indonesia. Based on Table 3, it can be seen that each Islamic bank does not have any similarity related to interbank efficiency performance, this is indicated by the p-value of the F-Statistic of 0.001. Up to the $1 \%$ significance level the first hypothesis proposed in this study proved that each bank has a level of efficiency performance that is not always the same. This means that each bank operates on an optimal scale that is relatively different, allegedly the difference in efficiency 
is caused by intense competition between the banks themselves so that certain banks cannot operate optimally.

Table 3. One Way ANOVA Results of Sharia Bank Efficiency Levels

\begin{tabular}{cccc}
\hline Measuring Efficiency & F-Statistic & P-Value & Finding \\
\hline VRS & 3,554 & 0,001 & Different \\
\hline
\end{tabular}

Souce: SPSS 24 output results (2019)

With the inequality of results from several banks, the grouping is done based on the level of efficiency. This grouping is done by Homogeneus Subsets test which aims to classify each Islamic bank based on the inefficiency risk that is owned by each bank, as shown in Table 4.

Table 4. Homogeneous Test Results Subsets

\begin{tabular}{ccc}
\hline Bank Code & Subsets 1 & Subsets 2 \\
\hline BBS & 0,9468 & 0,9762 \\
BMSI & 0,9762 & 0,9843 \\
BJBS & 0,9843 & 0,9883 \\
BCAS & 0,9883 & 0,9972 \\
BNIS & & 1,0000 \\
BMI & & 1,0000 \\
BRIS & & 1,0000 \\
BSM & & 1,0000 \\
BPS & & 1,0000 \\
BVS & & 0,7020 \\
MBS & & \\
\hline Sig. & 0,0520 & \\
\hline
\end{tabular}

Souce: SPSS 24 output results (2019)

Based on the results in Table 4 of the Homogeneous Subsets Test on VRS it can be seen that the efficiency level of sharia banks forms two main groups, namely the first group is sharia banks which are very risky to experience inefficiency, then in the second group shows sharia banks that are quite at risk of experiencing inefficiency. In the first group, Bank Bukopin Syariah, Bank Mega Syariah Indonesia, Bank Jabar Banten, Bank BCA Syariah are in the group with a very risky category of experiencing inefficiency. In the second group, Bank Muamalat, Bank BRI, Bank Syariah Mandiri, Bank Panin Syariah, Bank Victoria Syariah and Maybank Syariah are in the second group which means it is quite risky to experience inefficiency but it still tends to be safe because the efficiency assessment score obtained 1 or $=1,000$.

Meanwhile, the model selection technique in panel data regression is used to obtain a more dominant regression model. The results of the model selection using the Chow test and Hausmann test on the available data. Based on the results of the model selection, the panel data regression model chosen is the Fixed Effect (FE) time series model. The results of the feasibility test panel panel regression models can be expressed with an $\mathrm{F}$ statistical value of 14.5062 with a probability of 0.0000 . Using $\alpha$ of 0.05 shows that the probability (F-statistic) is smaller than 0.05 (5\%), then $\mathrm{HO}$ is rejected and $\mathrm{Ha}$ is accepted, so it can be concluded that 
the FE model can be used to explain the effect of efficiency on the competitiveness of commercial banks sharia in Indonesia.

Tabel 5. Model Fixed Effect (Time Series)

\begin{tabular}{|c|c|c|c|}
\hline \multicolumn{4}{|c|}{ Dependent Variabel: RCA } \\
\hline \multicolumn{4}{|c|}{ Method: Panel Least Squares } \\
\hline Variable & Coefficient & t-Statistic & Prob. \\
\hline VRS & 0,209515 & 0,346308 & 0,7305 \\
\hline $\mathrm{C}$ & 0,641081 & 1,068275 & 0,2902 \\
\hline \multicolumn{4}{|c|}{ R-Squared = 0,496013 } \\
\hline & F-Statistic $=$ & $584(0,000)$ & \\
\hline
\end{tabular}

Souce: Eviews 9 output results (2019).

The t-test results from the FE model as shown in Table 5 where the VRS that represents the efficiency performance shows a t-statistic value of 0.346308 with a probability of reaching 0.7305 . This means that the $t$-statistic value is smaller than $t$ table, then $\mathrm{H}_{0}$ is accepted and $\mathrm{H}_{\mathrm{a}}$ is rejected. So it can be concluded that efficiency does not significantly influence competitiveness. Based on the results of panel data regression analysis, the coefficient of determination shown by $\mathrm{R}$-squared is 0.496013 . This reflects that fluctuations in the efficiency value of Islamic banks (VRS variables) have a less powerful influence on the competitiveness of Islamic banks (RCA variables) of $49.60 \%$ while the rest are influenced by other variables outside the research model. The ineffectiveness of efficiency on competitiveness, shows that changes in performance efficiency at each bank will not have any impact on competitiveness. The results of this study are in line with research (Edward, 2013)which shows that there is no effect of efficiency on the competitiveness of Islamic banks with a significance level of $5 \%$, obtained p-value on the VRS variable of 0.8851 . However, the results of this study contradict the research Hafidz \& Astuti (2013)which states that the increasing level of bank competition will encourage banks to act more efficiently.

Based on the analysis of differences in the level of efficiency of Islamic banks it was found that overall Islamic banks have different levels of efficiency. The difference in efficiency levels shows that some Islamic banks are able to maximize their inputs and outputs perfectly. While several other Islamic banks have not reached the level of efficiency although it is almost close to perfect efficiency. The factors that affect technical inefficiency are the less optimal use of input capacity, where the addition of inputs is not accompanied by the addition of the same output.

This was mentioned in Akbar (2014)which stated that the performance of each DMU was quite good in raising funds and channeling them with inputs, but still lacked support from external conditions. Akbar (2014); Coelli, Prasada Rao, O'Donnell, \& Battese (2005)revealed that perfect competition, government regulations, financial constraints, etc. can cause a company to not operate at the optimum scale. In order to improve the efficiency of Islamic banking, especially for banks that are not yet efficient, it is necessary to have a comprehensive socialization to the public in order to find out more about Islamic banks and the products in them. For Islamic banks that are already efficient, this will not affect the competitiveness of Islamic banks, except if there are Islamic banks that issue innovations or new products, then competition can occur in the struggle for resources. Thus an efficient bank will not have any impact on competitiveness.

In this study the measurement of efficiency is done by the DEA method through an input-oriented intermediation approach. Although in its introduction, the DEA method has 
been used by a number of previous researchers, but what distinguishes it is the comparison or merging of efficiency with competitiveness in order to see the extent to which the level of efficiency can win competition between Islamic banks.

\section{CONCLUSION}

Based on the results and discussion previously described, it can be concluded that in general, the level of efficiency of Islamic banks in Indonesia is still quite efficient although in several years during the study period there were banks that experienced a decrease in efficiency, this could have happened considering that efficiency was a picture a company's performance. If the performance of a company experiences an increase, the efficiency of the company will also experience an increase, though not always. Therefore, the inefficiency of a bank does not mean that the bank fails to improve its performance. This is due to many other factors that can affect efficiency. While the results of the calculation of efficiency of competitiveness do not indicate any influence on the competitiveness of Islamic banks. This is indicated by the existence of different levels of efficiency between Islamic banks which does not affect the competitiveness of each Islamic bank. Nevertheless, Islamic banks with low competitiveness or competitive level should continue to make efforts to disseminate and introduce Islamic products to the general public, because Islamic banks have enough products that are not recognized by the wider community so that the attractiveness of Islamic banks has not been able to compensate conventional banks. In addition, for further researchers who want to conduct further studies on the measurement of efficiency and competitiveness of Islamic banks should be able to expand the sample of research and observation on the research object expanded, so that not only Islamic banks, but also can be expanded with other scopes such as the banking industry as a whole. overall so that the results can be generalized throughout the banking industry.

\section{REFERENCES}

Adam, A. W. (1996). Daya saing industri tekstil \& produk tekstil Indonesia menghadapi AFTA tahun 2003. PPW-LIPI: Jakarta.

Akbar, N. (2014). Analisis Efisiensi Organisasi Pengelola Zakat Nasional Dengan Pendekatan Data Envelopment Analysis. Tazkia Islamic Finance and Business Review, 4(2), 760-784. https://doi.org/10.30993/tifbr.v4i2.35

Amirillah, A. (2014). Efisiensi Perbankan Syariah di Indonesia. JEJAK: Jurnal Ekonomi Dan Kebijakan, 7(2), 141-150. https://doi.org/10.15294/jejak.v7i2.3895

Balassa, B. (1965). Trade Liberalisation and "Revealed" Comparative Advantage. The Manchester School, 33(2), 99-123. https://doi.org/10.1111/j.14679957.1965.tb00050.x

Basyarah, I. (2016). Peningkatan Efisiensi dan Daya Saing Perbankan Syari'ah. HUMAN FALAH: Jurnal Ekonomi Dan Bisnis Islam, 3(1), 133-143.

Berger, A. N., Mester, L. J. (1997). Inside the black box: What explains differences in the efficiencies of financial institutions? Journal of Banking \& Finance, 21(7), 895-947.

Cahyaningsih, P., Purnomo, D., Harun, H., \& Hasmarini, M. I. (2017). Kinerja Beberapa Bank Syariah Berdasar Tingkat Efisiensi Melalui Pengukuran DEA. Cakrawala: Jurnal Studi Islam, 12(2), 133-140.

Casu, B., \& Girardone, C. (2009). Does Competition Lead to Efficiency? The Case of EU Commercial Banks (SSRN Scholarly Paper No. ID 1200362). Retrieved from Social Science Research Network website: https://papers.ssrn.com/abstract=1200362 
Coelli, T. J., Prasada Rao, D. S., O’Donnell, C. J., \& Battese, G. E. (Eds.). (2005). Data Envelopment Analysis. In An Introduction to Efficiency and Productivity Analysis (pp. 161-181). https://doi.org/10.1007/0-387-25895-7_6

Edward, D. (2013). Pengaruh Tingkat Efisiensi Terhadap Daya Saing Perbankan Nasional Periode 2009-2010. Proceeding Research Day, 23.

Fathony, M. (2017). Analisis Efisiensi Perbankan Nasional Berdasarkan Ukuran Bank: Pendekatan Data Envelopment Analysis. Jurnal Keuangan Dan Perbankan, 15(1), $54-67$.

Hadad, M. D., Hall, M. J. B., Kenjegalieva, K. A., Santoso, W., \& Simper, R. (2011). Banking efficiency and stock market performance: an analysis of listed Indonesian banks. Review of Quantitative Finance and Accounting, 37(1), 1-20. https://doi.org/10.1007/s11156-010-0192-1

Hafidz, J., \& Astuti, R. I. (2013). Tingkat Persaingan dan Efisiensi Intermediasi Perbankan Indonesia (No. W/3/2013; pp. 1-49). Indonesian: Bank Indonesia.

Hidayati, N., Siregar, H., \& Pasaribu, S. H. (2017). Determinant of Efficiency of The Islamic Banking in Indonesia. Bulletin of Monetary Economics and Banking, 20(1), 29-48. https://doi.org/10.21098/bemp.v20i1.723

Huda, N., \& Nasution, M. E. (2014). Current Issues Lembaga keuangan Syariah. Kencana.

Iqbal, M. (2015). Regresi Data Panel (2) "Tahap Analisis" - Dosen Perbanas [Https://dosen.perbanas.id/]. Retrieved April 10, 2019, from https://dosen.perbanas.id/regresi-data-panel-2-tahap-analisis/

Ismail. (2011). Perbankan Syariah (1st ed.). Jakarta: Prenadamedia Group.

Karlinda, F. (2012). Analisis Daya Saing dan Faktor-Faktor yang Memengaruhi Permintaan Ekspor Mutiara Indonesia. Retrieved from http://repository.ipb.ac.id/xmlui/handle/123456789/60753

Karsinah, K., \& Cahya, A. R. K. (2014). Kinerja Bank Umum Syariah di Indonesia Tahun 2010-2012. JEJAK: Jurnal Ekonomi Dan Kebijakan, 7(2), 158-172. https://doi.org/10.15294/jejak.v7i2.3897

Khasanah, I., \& Laksito, H. (2010). Pengaruh Rasio CAMEL Terhadap Kinerja Perusahaan Perbankan Yang Terdaftar Di BEI (Other, Universitas Diponegoro). Retrieved from http://eprints.undip.ac.id/23347/

Loong, F., Kamarudin, F., Sufian, F., \& Naseem, N. A. M. (2017). Estimating Efficiency in Domestic and Foreign Islamic Banking and Its Determinants among Three Neighboring Countries - Malaysia, Indonesia and Brunei. International Journal of Economics and Management, 11(1), 237-258.

Muharam, H. (2007). Analisis Perbandingan Efisiensi Bank Syariah di Indonesia Dengan Metode Data Envelopment Analysis (periode Tahun 2005). Jurnal Ekonomi Dan Bisnis Islam, II, 80-166.

Nadiasari, A. I. (2018). Perbandingan Efisiensi Bank Umum Swasta di Indonesia Menggunakan Metode Data Envelopment Analysis (DEA) Periode Tahun 2010 2016. Perbanas.

Ramly, A. R., \& Hakim, A. (2017). Pemodelan Efisiensi Bank di Indonesia: Perbandingan antara Bank Syariah dan Bank Konvensional. Esensi: Jurnal Bisnis dan Manajemen, 7(2), 131-148. https://doi.org/10.15408/ess.v7i2.4989

Risfandy, T., Husa, P. P., \& Asrihapsari, A. (2016). Daya Saing Bank Syariah Di Sebuah Negara Religius: Temuan Empirik Dari Indonesia. 11.

Riyadi, S. (2017). Manajemen Perbankan Indonesia (Teori, Praktik dan Studi Kasus).Jakarta: RajaGrafindo Persada. 
Rosyadi, I. (2017). Komparasi Efisiensi Perbankan Syariah dan Perbankan Konvensional di Indonesia. Riset Akuntansi Dan Keuangan Indonesia, 2(1), 61-74. https://doi.org/10.23917/reaksi.v2i1.3683

Schaeck, K., \& Čihák, M. (2008). How Does Competition Affect Efficiency and Soundness in Banking? New Empirical Evidence (SSRN Scholarly Paper No. ID 1240856). Retrieved from Social Science Research Network website: https://papers.ssrn.com/abstract=1240856

Sugiarto. (2016). Metodologi Penelitian Bisnis. Yogyakarta: CV ANDI.

Tanjung, H., \& Devi, A. (2013). Metodologi Penelitian Ekonomi Islam. Gramata Pub.

Wahab, W. (2015). Analisis Faktor-faktor Yang Mempengaruhi Efisiensi Bank Umum Syariah di Indonesia Dengan Pendekatan Two Stage Stohastic Frontier Approach(Studi Analisis di Bank Umum Syariah). Economica: Jurnal Ekonomi Islam, 6(2), 57-76. https://doi.org/10.21580/economica.2015.6.2.794

Wijayanto, A., \& Sutarno, S. (2010). Kinerja Efisiensi Fungsi Intermediasi Bank Persero di Indonesia dengan Menggunakan DEA. Jurnal Keuangan Dan Perbankan, 14(1), 110121. 